\title{
A síntese química do DNA
}

\section{Um instrumento indispensável às manipulações genéticas}

\section{Introdução}

Há menos de 10 anos, a síntese química de DNA era um domínio esotérico, apanágio de alguns químicos especializados. Calculava-se, em 1975, que seriam necessários 20 anos para sintetizar um gene de $100 \mathrm{nu}$ cleotídeos segundo um esquema optimizado por computador (').

Actualmente é possível realizar este trabalho em poucas semanas: por exemplo nós sintetizámos recentemente um gene de 270 nucleótidos em cerca de um mês a partir de dinucleótidos protegidos. Esta proeza técnica ao alcance de um número crescente de laboratórios só é possível graças ao desenvolvimento acelerado das técnicas de síntese química, catalisado pelo advento das técnicas da Engenharia Genética. O alargamento contínuo do campo de aplicação dos fragmentos sintéticos de DNA, assim como o aspecto fundamental do estudo estrutural de certas sequências particulares, constituíram estímulos poderosos para os químicos orgânicos cujos esforços conduziram ao ajustamento e ao aperfeiçoamento das técnicas de síntese.

Apresentamos neste artigo um resumo geral da química que está na base da sintese de DNA tal como ela é praticada actualmente, e algumas das suas aplicaçðes.

\section{I - Princípios da síntese química de DNA}

A sintese química em solução de um oligodesoxinucleótido comporta as seguintes etapas:

1 - Preparação dos quatro desoxinuclétidos: timidina, desoxicitidina, desoxiadenosina e desoxiguanosina completamente protegidos. Estes são os blocos fundamentais para a sintese.

2 - Desprotecção selectiva de dois desoxinucleótidos a condensar, de maneira a libertar em cada um dos blocos unicamente as funçðes implicadas na formação da ligação internucleotídica.

3 - Condensação dos compostos assim gerados para formar um dímero inteiramente protegido.

4 - Extensão da cadeia de DNA repetindo as reacçð̃es das etapas 2 e 3 até à obtenção de um oligodesoxirribonucleótido completamente protegido.

5 - Desprotecção sequencial e controlada do oligodesoxirribonucleótido.

6 - Isolamento, purificação e caracterização.

Quando a extensão da cadeia desoxirribonucleotídica é realizada em fase sólida, são necessárias algumas etapas suplementares: i) funcionalização de um polimero insolúvel

ii) fixação do primeiro desoxirribonucleótido protegido da cadeia oligodesoxirribonucleótida a sintetizar, sobre a função do suporte sólido

iii) clivagem da cadeia de DNA do suporte sólido

\section{1 - Preparação dos blocos de base para a síntese}

As substâncias de base na sintese de DNA são os quatro desoxirribonucleótidos: timidina, desoxicitidina, desoxiadenosina e desoxiguanosina; (obtidos por degradação de ADN de origem natural). (Esquema 1).

Esquema

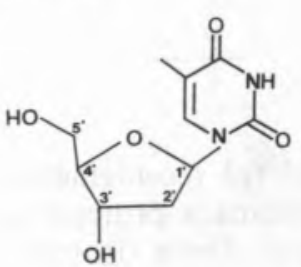

Timidina

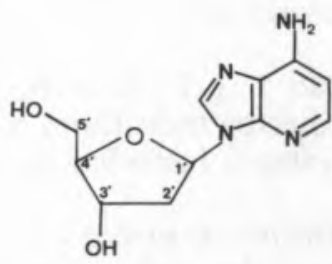

Desoxiadenosina

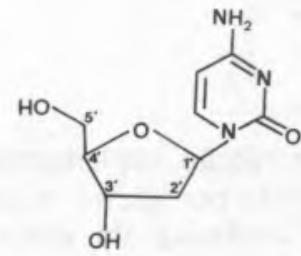

Desoxicitidina

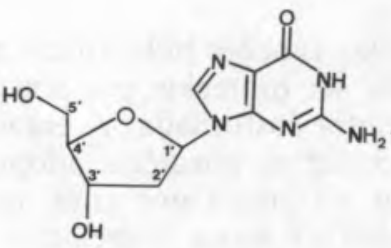

Desoxiguanosina
$\mathrm{Na}$ molécula desoxinucleosídica podem-se distinguir três centros que vão ser objecto de três formaçס̄es distintas: as bases, as funçס̄es hidroxílicas em posição $5^{\prime}$ e posição $3^{\prime}$.

\section{a) Protecção das funçס̃es aminas exocíclicas}

As bases que possuem funçðes aminas primárias (a timidina não possui) têm que ser protegidas.

Esta proteç̧ão é permanente visto que o centro aminado não está implicado nas reacçðes de extensão oligomérica. Portanto os grupos protectores devem ser estáveis ao longo de todas as etapas de síntese. No entanto eles devem poder ser retirados no fim da síntese em condiçð̄es que preservem a integridade da molécula fi-

\footnotetext{
* Investigador no Laboratório de Genética Aplicada. Département de Biologie Moléculaire. Université Libre de Bruxelles Bélgica.
} 
nal. Os grupos que, nas estratégias de síntese mais utilizadas, melhor satisfizeram estas condiçðes, são o grupo benzoílo para a desoxicitidina e a desoxiadenosina e o grupo isobutanoílo para a desoxiguanosina $\left({ }^{2}\right)$. A sua introdução tem de ser selectiva a fim de não bloquear os grupos hidroxílicos do ciclo desoxirribofuranosilo. Estes grupo são objecto de uma protecção transitória que pode ser especificamente removida após acilação dos grupos aminados ( $\left.{ }^{3}\right)$ (Exemplo: esquema 2).

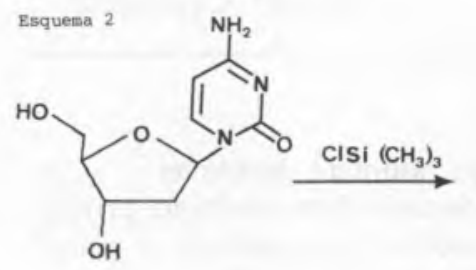

Desoxicitidinà<smiles>O=C(Nc1ccn(C2CC(O)C(CO)O2)c(=O)n1)c1ccccc1</smiles>
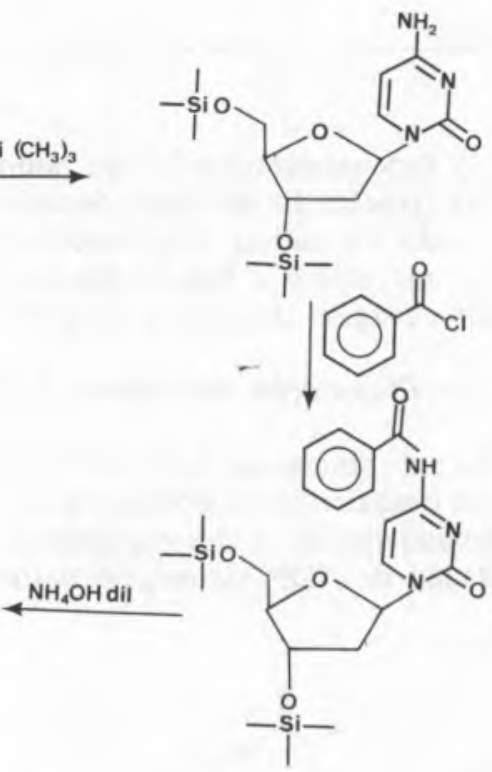

Uma protecção suplementar original foi recentemente introduzida por várias equipas, destinada a proteger a função lactâmica da desoxiguanosina, fonte de reacçøes secundárias durante as reacçð̄es de condensação e de fosforilação $\left({ }^{4}\right)$.

\section{b) Transformação dos grupos hidroxílicos}

Das funçð̄es hidroxílicas em posição $5^{\prime}$ e $3^{\prime}$ uma tem de ser protegida por um grupo protector transitório, a outra fosforilada. A escolha do centro a fosforilar depende da estratégia adoptada.

A estratégia que consiste em fosforilar a posição $3^{\prime}$ deu até agora os melhores resultados e tem sido utilizada nos métodos gerais de fosfatotriester e de fosfitotriéster.

a) A protecção do grupo hidroxílico em posição $5^{\prime}$ tem de ser temporária. Ela tem de ser removida antes de cada etapa de condensação durante a extensão da cadeia desoxirribonucleotídica. O grupo protector deve neste caso possuir as propriedades seguintes:

i) poder ser introduzido selectivamente em posição $5^{\prime}$ deixando intacta a função hidroxílica em posição 3 '; ii) poder ser retirado em condiçð̄es suaves que não dêem lugar a nenhuma reacção secundária;

iii) ser estável em todas as etapas de sintese, de desprotecção e de purificação que se seguem à sua introdução;

i) eventualmente facilitar pela sua introdução a purificação dos intermediários de sintese.

Entre outros grupos introduzidos com bons resultados o 4,4'-dimetoxitritilo é um dos mais correctamente adoptados $\left(^{5}\right)$. É introduzido através do seu cloreto ti- rando-se benefício da sua selectividade pela posição $5^{\prime}$ devido a factores estéricos. (Exemplo: esquema 3 ).

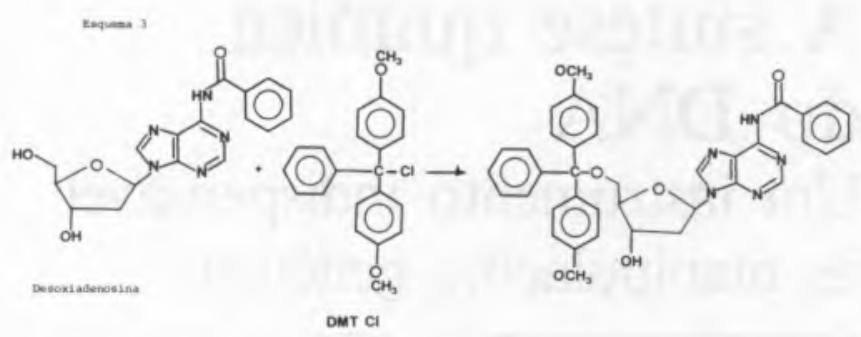

O grupo 4,4'-dimetoxitritilo pode ser quantitativa e rapidamente retirado em condiçðes de baixa acidez (Ex.: ácido dicloroacético, brometo de zinco) sem ruptura ou com ruptura insignificante da ligação glicosídica; esta reacção conduz à formação do catião dimetoxitritilo de côr laranja cuja absorvância pode ser medida espectrofotometricamente. Esta medida é particularmente útil na síntese em fase sólida pois ela é a única indicação da eficácia das reacçð̃es de condensação durante a construção da cadeia oligonucleotídica.

B) A fosforilação em posição $3^{\prime}$ dos nucleosídeos protegidos nas bases e no grupo hidroxílico em $5^{\prime}$ pode conduzir, segundo a estratégia escolhida, a um bloco completamente protegido, ou a uma espécie fosforilada activa capaz de reagir directamente com outro bloco desoxinucleotídico desprotegido em posição $5^{\prime}$ para formar a ligação internucleotídica.

Numerosos agentes de fosforilação têm sido utilizados em síntese de oligodesoxirribonucleotídeos, sobretudo na metodologia do fosfatotriéster (Esquema 4).

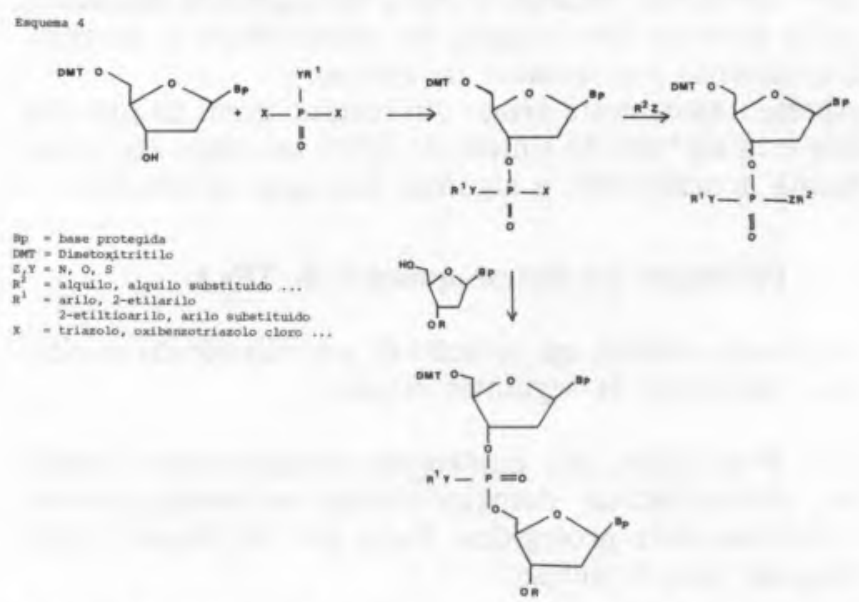

Um dos substituintes do átomo de fósforo protege de maneira permanente o anião fosfato responsável pelos fracos rendimentos das reacções de condensação, assim como das dificuldades crescentes de purificação e de solubilidade com o comprimento dos oligómeros, surgidas na metodologia inicial dos fosfatodiéster ( ${ }^{6}$ ).

O outro substituinte tem um papel de proteç̧ão temporária destinada a ser substituida pela ligação fosfato internucleotídica.

O grupo protector permanente deve possuir uma estabilidade total durante as reaçð̃es de eliminação dos grupos protectores temporários e durante as reacçðes de condensação. Não deve interferir negativamente com o rendimento e a eficácia destas últimás. Ele tem no entanto que ser retirado especificamente no fim da sintese sem provocar a ruptura concorrente das ligaçōes internucleotídicas. 
O grupo protector transitório deve ser suficientemente estável para permitir o isolamento, a purificação e a estocagem dos blocos desoxinucleotídicos completamente protegidos. A sua eliminação deve ser específica e rápida em condiçðes que preservem os grupos protectores permanentes e o grupo protector temporário em posição $5^{\prime}$.

Os grupos ortoclorofenilo $\left(\mathrm{R}=\mathrm{o} . \mathrm{ClC}_{6} \mathrm{H}_{4}\right.$ com $\left.\mathrm{Y}=0\right)$ permanente e o cianoetilo $\left(\mathrm{R}=\mathrm{Cl}_{2} \mathrm{CH}_{2} \mathrm{CN}\right.$ com $\left.\mathrm{Z}=0\right)$ temporário (ver esquema 4) são exemplos de grupos muito utilizados na metodologia dos fosfatotriéster $\left({ }^{7}\right)$ (Exemplo: esquema 5).
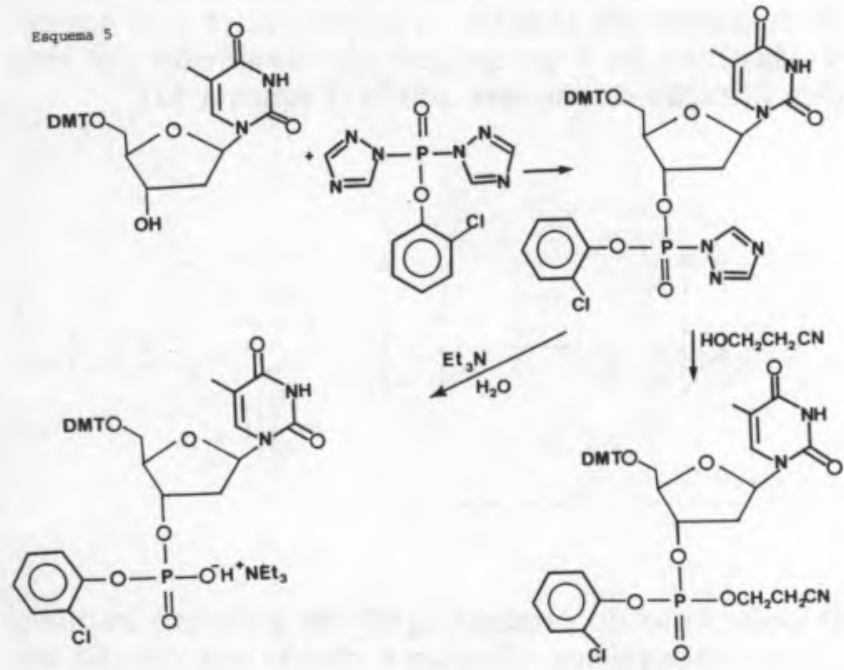

O grupo protector permanente correntemente utilizado na metodologia do fosfitotriéster é o radical metilo. $\mathrm{O}$ terceiro substituinte do átomo do fósforo é um grupo azodialquilo introduzido em substituição de um átomo de cloro, o qual confere uma reactividade particularmente forte ao intermediário fosfocloridrito (utilizado durante o desenvolvimento inicial do método) ${ }^{8}$ ) que o torna instável e de emprego pouco cómodo.

Os compostos diisopropilamino e morfolino-fosforoamidito possuem um bom compromisso de reactividade-estabilidade (Exemplo: esquema 6).
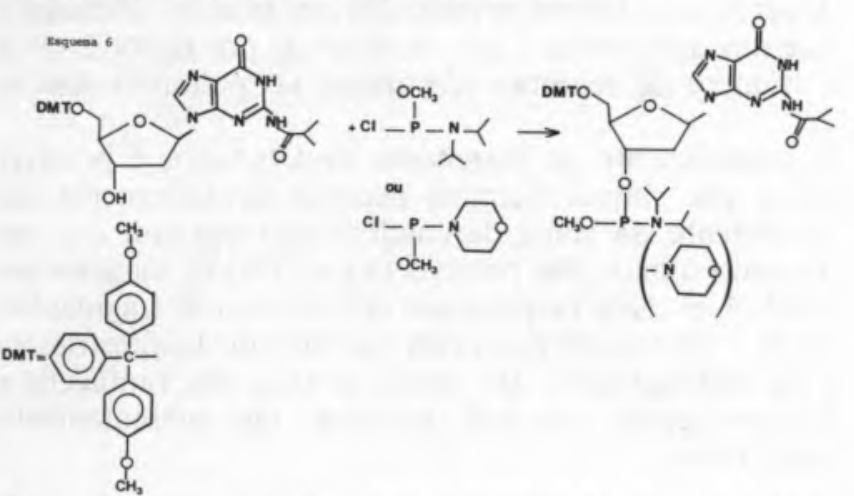

É importante sublinhar que o sucesso da síntese química de DNA se baseia sobretudo na preparação destes blocos de base, isto é, na escolha dos diferentes grupos protectores, no rendimento das diferentes reaç̧ð̄es e na pureza dos desoxinucleótidos completamente protegidos.

\section{2 -Desprotecção selectiva}

Para poder condensar dois desoxinucleótidos pelo método do fosfato triéster, é necessário libertar separada- mente por um lado a função fosfato e por outro o grupo hidroxílico $5^{\prime}$ das suas protecçðes temporárias. Por exemplo, o grupo dimetoxitritilo é retirado em condiçðes ácidas suaves e o grupo cianoetilo em condiçðes básicas suaves.

\section{3 - Reacções de Condensação}

A reacção de condensação necessita evidentemente da formação de espécies activas capazes de reagir com bons rendimentos sem formação de produtos secundários.

A activação do fosfatodiéster é frequentemente realizada pela acção conjugada de um cloreto de arilosulfonilo e de uma amina heterocíclica, ou de uma sulfonamida preparada antecipadamente a partir deste tipo de compostos $\left({ }^{10}\right)$ (Esquema 7).

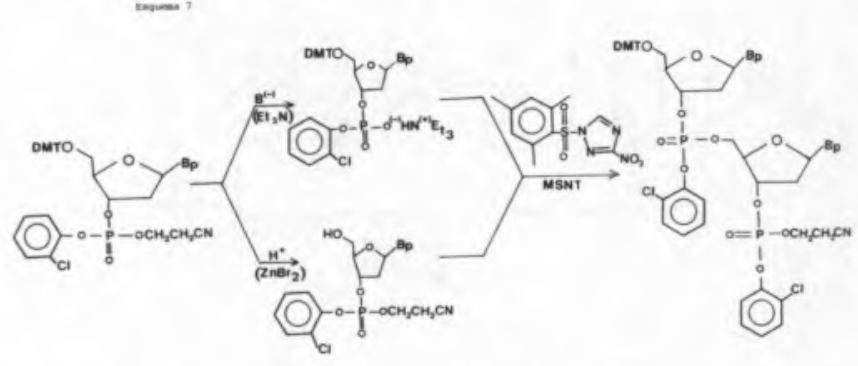

A activação dos fosforoamiditos é realizada por um agente de protonação, ácido fraco (Ex.: o tetrazole $\mathrm{pKa}=4,9)$ que acelera a quebra do grupo dialquilamina e favorece o ataque pela função hidroxílica que vai estabelecer a ligação internucleotídica (11). Não é portanto possível dentro desta metodologia eliminar o grupo dimetoxitritilo em presença do grupo fosforoamidito (Esquema 8).

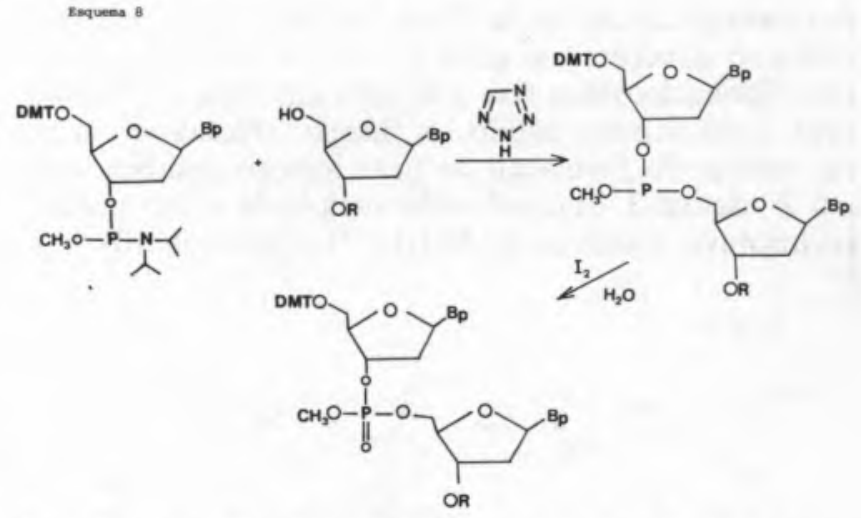

4 - Construção da cadeia oligodesoxinucleotídica

Na síntese em solução e pela metodologia do fosfatotriéster a extensão da cadeia polinucleotídica pode fazer-se de maneira alternada no sentido $3^{\prime} \rightarrow 5^{\prime}$ ou $5^{\prime} \rightarrow 3$ ' visto que se pode desproteger o grupo hidroxílico na extremidade $5^{\prime}$ ou trifosfato na posição $3^{\prime}$ do oligómero em construção. Dois oligómeros podem igualmente ser condensados um com o outro. Devido à sensibilidade dos fosforoamiditos às condiçðes ligeiramente ácidas, esta flexibilidade própria aos triesterfosfatos não se aplica ao método do fosfitotriéster que não foi desenvolvido em solução. A síntese em solução permite a detecção de reacçð̋es secundárias de maneira mais directa que a síntese em fase sólida. Ela permite a identificação e a compreensão da origem dos produtos 
parasitas e portanto possibilita a intervenção sobre os parâmetros correctores (Esquema 9).
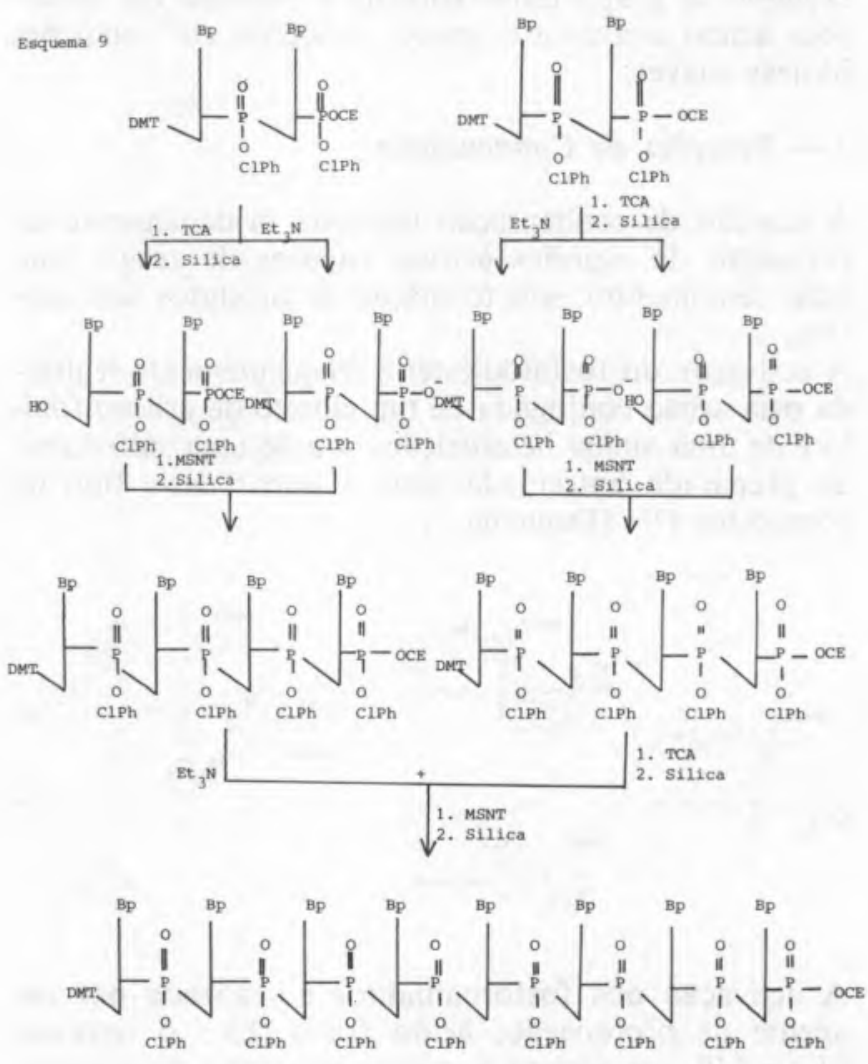

Bp = citosina ou adenina ou guanina protegida, ou timina.

C1Ph $=2$-clorofeno 1

CI = cianoetilo

TCA $=$ acido tricloroacetico

MSNT = mesitilenosulfoni1-3-nitrotriazolo

A extensão da cadeia de DNA em fase sólida realiza-se numa só direcção (em geral $3^{\prime} \rightarrow 5^{\prime}$ ) a partir de um desoxirribonucleosídeo fixo por uma das funçð̃es hidroxílicas a um suporte sólido. A fixação efectua-se em geral através da formação de uma ligação amídica entre um 2 '-desoxi-3'-succinilorribonucleósido e um polímero insolúvel aminado $\left(\beta-\mathrm{NH}_{2}\right)\left({ }^{12}\right)$ (Esquema 10$)$.

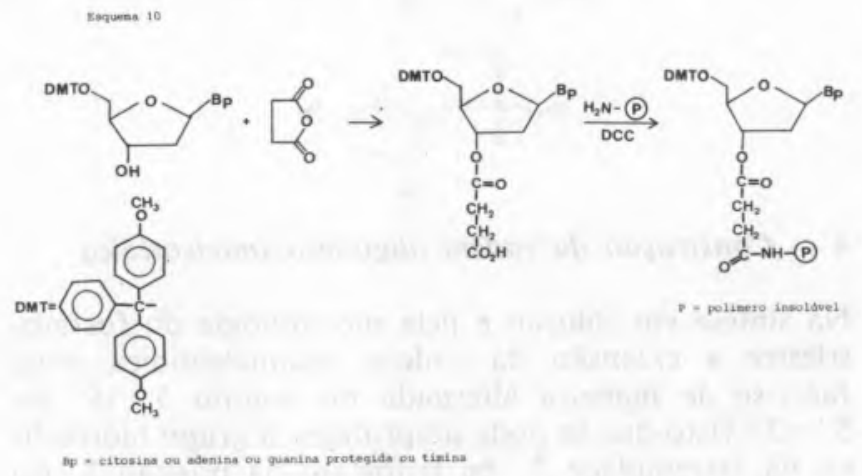

O poliestirenodivinilbenzeno, a resina composta polidimetilacrilamida-kieselguhr, a sílica, as esferas de vidro de porosidade controlada, a celulose, o co-polimero teflo-poliestireno são exemplos de polimeros insolúveis correntemente utilizados.

A extensão da cadeia polinucleotídica em fase sólida consiste na repetição de um ciclo que compreende essencialmente:
1) A reacção de desprotonação do grupo hidroxilico em $5^{\prime}$ do primeiro nucleósido (ou da cadeia em crescimento) fixo no polimero insolúvel.

2) A reacção de condensação entre a função hidroxilica libertada e a espécie nucleotídica introduzida em solução e activada "in situ" no átomo de fósforo em posição $3^{\prime}$.

Com o método do fosfatotriéster uma terceira reacção de oxidação do fosfito em fosfato é necessária. Uma reacção suplementar é por vezes efectuada. Ela visa o bloqueamento da ligeira percentagem dos grupos hidroxílicos que não reagiram na reacção de condensação a fim de os desactivar para as reacçð̃es ulteriores.

Os reagentes em excesso, os sub-produtos e os solventes das reacçð̄es e de lavagem são eliminados por simples filtração do suporte sólido (Esquema 11).

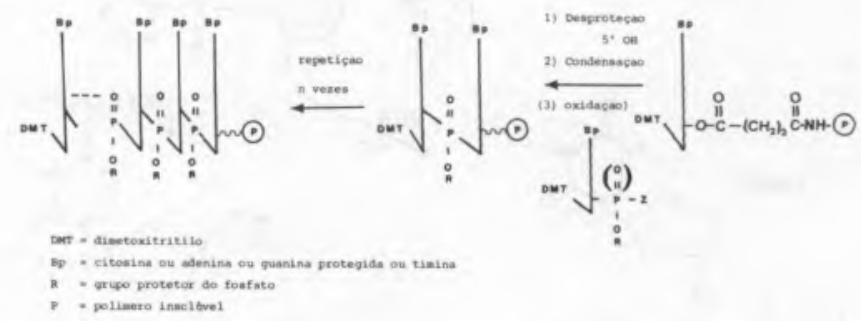

$\mathrm{O}$ isolamento do produto ligado ao polímero insolúvel é por consequência simples e rápido em relação aos métodos convencionais em solução. $\mathrm{O}$ conjunto das operaçð̃es presta-se bem à automatização.

Uma desvantagem da fase sólida é a cinética desfavorável. Para conseguir reaç̧ð̃es completas dentro de tempos razoáveis é indispensável utilizar excessos importantes de reagentes cuja pureza é portanto crítica. Traços de impurezas reactivas podem inibir completamente a reacção de condensação.

Em fase sólida a acumulação de produtos indesejáveis é inevitável visto não haver purificação em nenhuma etapa da extensão do fragmento de DNA. Uma maneira de minimizar este inconveniente consiste em utilizar dímeros ou trímeros preparados em solução, estratégia que nós adoptámos e que diminui de um factor 2 ou 3 o número de reacçōes efectuadas no polímero insolúvel.

O comprimento do fragmento de DNA que é possível obter por síntese química depende evidentemente do rendimento da etapa de condensação que tem que ser mantido o mais alto possível (90 a $95 \%$ ) de maneira reprodutível. Nós preparamos correntemente fragmentos de 30 a 50 nucleótidos pelos métodos do fosfatotriéster e do fosfitotriéster. Do ponto de vista das vantagens e inconvenientes, os dois métodos são presentemente equivalentes.

\section{5-Desprotecção}

A desprotecção do fragmento de DNA é uma operação delicada que deve preservar a integridade do edifício molecular. Reaç̧ðes incompletas ou uma degradação parcial conduzem a uma mistura complexa de produtos.

A desprotecção compðe-se de 3 etapas distintas:

I) transformação dos grupos triesterfosfatos em diesterfosfatos; 
II) Desprotecção das bases;

III) Desprotecção da função OIH terminal em 5'.

I) A desprotecção dos grupos fosfatos é uma fonte possível de ruptura internucleotídica. Esta pode ser minimizada utilizando reagentes selectivos antes de desproteger as bases.

Se a extensão da cadeia de DNA for realizada pelo método do fosfatotriéster em fase sólida, a clivagem do suporte insolúvel efectua-se com o mesmo reagente de desprotecção dos grupos fosfatos clorofenilados, por exemplo com o 2-nitrofenilcarbaldoximato de tetrametilguanidina. $\mathrm{O}$ grupo metilo utilizado com o método do fosfitotriéster é deslocado por ataque nucleofilico pelo anião tiofenalato antes da clivagem. Esta é efectuada em condiçð̃es suaves.

II) As aminas exocíclicas das bases são desaciladas por amonólise a $50^{\circ} \mathrm{C}$. Este tratamento provoca uma ruptura, que não é desprezável, das ligaçð̋es fosfatos internucleotídicas quando o fosfato está na forma de triéster; esta é a razão pela qual se converte antecipadamente e selectivamente o fosfatotriéster em fosfatodiéster.

III) $\mathrm{O}$ grupo protector da função hidroxílica em posição $5^{\prime}$ é o último a ser retirado (pelo ácido acético $80 \%$ no caso do grupo dimetoxitritilo). É conservado até ao fim para impedir a formação de triésteres fosforicos cíclicos que conduzem a estruturas oligodesoxirribonucleótidicas com ligaçðes $5^{\prime} \rightarrow 5^{\prime}$, durante as primeiras etapas de desprotecção. Devido ao seu carácter hidrófobo o grupo dimetoxitritilo protector da função 5 'OIH facilita o isolamento do produto por cromatografia de sílica em fase inversa (Esquema 12).

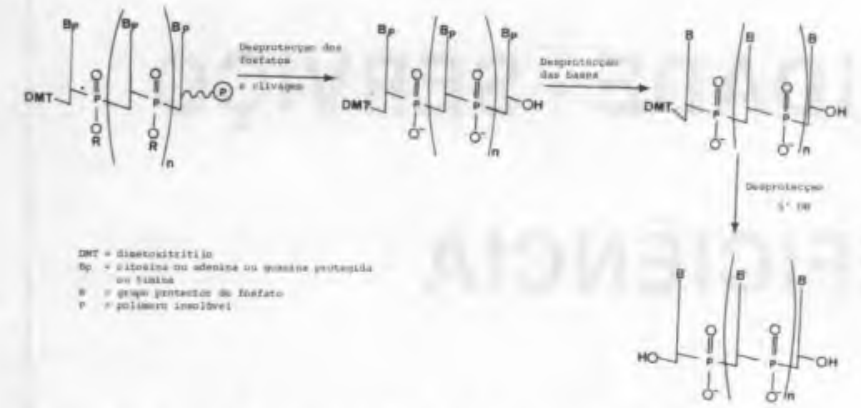

\section{6 - Isolamento, purificação e caracterização}

Os métodos de isolamento e de purificação correntemente utilizados são a cromatografia de DEAE-celulose, de Sefadex, de camada fina de sílica, a cromatografia liquida a alta pressão (IPLC) com coluna de sílica de fase inversa ou de troca de catiðes e a electroforese preparativa em poliacrilamida.

A caracterização do produto isolado e marcado numa das extremidades com um radioisótopo pode ser efectuada pelo método de sequenciação de DNA de Maxam e Gilbert $\left({ }^{13}\right)$. É no entanto necessário um reajustamento das condiçð̄es das reacçð̄es aos fragmentos de pequeno comprimento $\left({ }^{14}\right)$. Um outro método conhecido pelo nome de "Wandering spot" baseia-se na análise a duas dimensőes (electroforese em acetato de celulose, seguida de cromatografia em camada fina de DEAE-celulose) dos fragmentos de oligonucleotido sin- tético marcado numa extremidade, obtidos por digestão parcial com uma exonuclease $\left({ }^{15}\right)$. Este método restringe-se a fragmentos de comprimento inferior a 20 nucleotidos.

\section{II - $\mathbf{O}$ campo das aplicações}

As aplicaçð̄es dos oligodesoxirribonucleótidos de sequência definida cobrem quase todos os aspectos da investigação que implicam a recombinação de DNA tanto no que diz respeito à construção, à identificação e à caracterização de clones bacterianos particulares, como à manipulação do DNA clonado com o fim de modificar a sua estrutura.

Nos campos da determinação de sequências de DNA, do estudo das interreacçðes proteína-DNA ou da análise estrutural do DNA, os oligodesoxirribonucleótidos sintéticos têm-se revelado uma arma extremamente útil. A coordenação das competências e a conjugação dos esforços conduziram no nosso laboratorio a alguns sucessos no domínio da Engenharia Genética aplicada à medicina.

A sintese química de DNA de sequência definida possibilitou a varredura (screening) de bancos de clones e o isolamento de estirpes bacterianas como a alfa-1-antitripsina, a antitrombina III e a uroquinase $\left({ }^{16}\right)\left({ }^{17}\right)$ ${ }^{(18)}$ e a sintese total da sequência de DNA que codifica para a somatocrinina humana cuja introdução num vetor plasmídico $\left({ }^{19}\right)$ possibilitou a expressão deste factor hormonal na bactéria $\left(^{20}\right)$. Estes exemplos ilustram, de maneira não exaustiva a importância da química de síntese dos ácidos nucleicos em qualquer programa de engenharia genética: podemos prever, sem qualquer dúvida, que esta importância continuará a aumentar intensamente no futuro.

\section{BIBLIOGRAFIA}

(1) G.J. Powers, R.L. Jones, G.A. Randall, M.IH. Garuthers, J.H. van de Sande e H.G. Khorana, J. Am. Chem. Soc., 97, 975 (1975).

(2) E.L. Brown, R. Belagaje, M.J. Ryan e H.G. Khorana, Methods in Enzymology 68, 109 (1979).

(3) G.S. Ti, B.L. Gaffney e R.A. Jones, J. Am. Chem. Soc., 104, 1316 (1982).

(4) a) S.S. Jones, C.B. Reese, S. Sibanda e A. Ubasawa, Tet. Lett., 22 (47) 4755 (1981). b) IH.P. Daskolov, M: Sekine e T. Hata, Bull. Chem. Soc. Japan, 54, 3076 (1981). c) B.L. Gaffney e R.A. Jones, Tet. Lett., 23 (22) 2257 (1982). d) T. Trichtinger, R. Charubala e W. Pfleiderer, Tet. Lett., 24 (7) 711 (1983). e) M. Sekine, J. Matsuzaki e T. Hata, Tet. Lett., 23 (50) 5287 (1982). f) T. Kamimura, M. Tsuchiya, K. Moura, M. Sekine e T. Hata, Tet. Lett., 24 (27) 2775 (1983).

(5) K.L. Agarwal, A. Yamasaki, P.J. Cashion e IH.G. Khorana, Angew. Chem. Int. Ed. Engl., 11, 451 (1972).

(6) IH.G. Khorana, Science 203, 614 (1979).

(7) N. Katagiri, K. Itakura e S.A. Narang, J. $A m$. Chem. Soc., 97, 7332 (1975).

(8) R.L. Letsinger e W.B. Lursford, J. Am. Chem. Soc., 98, 3655 (1976).

(9) L.J. McBride e M.H. Garuthers, Tet. Lett., 24 (3) 245 (1983).

(10) a) S.S. Jones, B. Rayner, C.B. Reese, A. Ubasawa e M. Ubasawa, Tetrahedron 3075 (1980). b) V.A. Efimov, S.V. Reverdatto e O.G. Chakhmakhcheva, Tet. Lett., 23 (9), 961 (1982). 
(11) S.L. Beaucage e M.H. Caruthers, Tet. Lett., 22 (20) 1859 (1981).

(12) a) H. Iti, Y. Ike, S. Ikuta e K. Itakura, Nucl. Acids Res., 10, 1755 (1982). b) M.J. Gait, H.W.D. Matthes, M. Singh e R.C. Titmas, J. Chem. Soc., Chem. Commun., 37 (1982).

(13) A.M. Maxam e W. Gilbert, Proc. Natl. Acad. Sc. USA, 74, 560 (1977).

(14) a) E. Jay, A.K. Seth, Y. Rommens, A. Sood, G. Jay, Nucl. Acids Res., 10 (20), 6319 (1982). b) A.M. Banaszuk, K.V. Deugou, J. Sherwood, M. Michalak, B.R. Glick, Anal. Biochem., 128, 281 (1983).
(15) C.P.D. Tu, E. Jay, C.P. Bahl e R. Wu, Anal. Biochem., 74, 73 (1976).

(16) Bollen, A., Chimie Nouvelle (Fevr. 1984).

(17) A. Bollen, A. Herzog, A. Cravador, P. Hérion, P. Chuchana, A. Van der Straten, R. Loriau, P. Jacobs and A. Van Elsen, DNA, 2, 255 (1983).

(18) P. Jacobs, A. Cravador, R. Loriau, F. Brockly, B. Colau, P. Chuchana, A. Van Elsen, A. Herzog and A. Bollen, DNA, 4, 139 (1985).

(19) A. Cravador, P. Jacobs, A. Van Elsen, C. Lacroix, B. Colau, P. Van Alphen, A. Herzog and A. Bollen, Biochimie, 67, 829 (1985).

(20) Resultados não publicados.

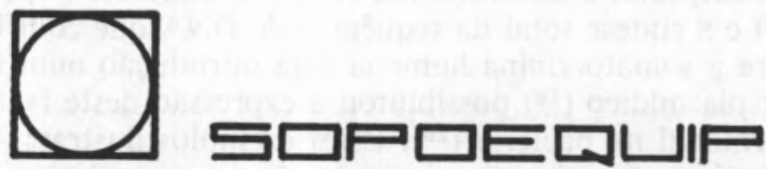

PRODUTOS E EQUIPAMENTOS PARA A INDÜSTRIA E LABORATORIOS LDA

\section{DINAMISMO - QUALIDADE - SERVIÇO}

\section{ESCOLHA - EFICIÊNCIA}

PEÇA-NOS A LISTA DAS NOSSAS REPRESENTADAS

ALGUMA LHE INTERESSARÁ!

Estamos à distância do seu telefone...

QUINTA DA PIEDADE, LOTE $12-1 .^{\circ}$ 